\title{
Preoperative Uterine Artery Embolisation for Large Uterine Fibroids with Subsequent Uterus Preservation - Three Case Histories and Review of the Literature
}

\author{
Präoperative Myomembolisation als Option bei großem Uterus myomatosus \\ und dringendem Wunsch nach Uteruserhalt - 3 Kasuistiken und Literaturübersicht
}

Authors

Affiliations

\section{David ${ }^{1}$, T. Kröncke ${ }^{2}$}

${ }^{1}$ Klinik für Gynäkologie, Charité Campus Virchow-Klinikum, Berlin

2 Klinik für Strahlenheilkunde, Charité Campus Virchow-Klinikum, Berlin
Key words

- myoma

- myomectomy

- myoma embolisation

Schlüsselwörter

- Myom

- Myomektomie

- Myomembolisation

\author{
received 24.2.2012 \\ revised 2.4.2012 \\ accepted 17.4.2012
}

\section{Bibliography}

DOI http://dx.doi.org/

10.1055/s-0031-1298589

Geburtsh Frauenheilk 2012; 72 :

539-542 @ Georg Thieme

Verlag KG Stuttgart · New York ·

ISSN 0016-5751

\section{Correspondence}

Prof. Dr. med. Matthias David

Charité Campus

Virchow-Klinikum

Klinik für Gynäkologie

Augustenburger Platz 1

13353 Berlin

matthias.david@charite.de

\section{Abstract}

\section{$\nabla$}

Uterine artery embolisation (UAE) is an established procedure to treat uterine fibroids as an alternative to surgery. The combination of both approaches is reserved for only a few cases. A preoperative UAE (PUAE) contributes to reducing bleeding complications and helps preserve the uterus. We report here on 3 patients, each with very large fibroid (all $>1100 \mathrm{~g}$ ), who were successfully treated by interdisciplinary hybrid intervention (embolisation followed by surgery). Preserving the uterus was a "sine qua non" for all 3 patients. As discussed in some articles, PUAE should be considered when treating patients who wish to preserve their uterus at all costs but who are considered preoperatively to be at increased risk of bleeding and/or patients who are considered to be at high risk of requiring a hysterectomy "for technical reasons". The additional costs of embolisation can be set against the potentially shorter hospitalisation times due to the more favourable intraoperative and postoperative course, the savings arising from the reduced need for blood transfusions, and the greater patient satisfaction.

\section{Introduction}

Most reports on greatly enlarged uteri and the management of such enlarged uteri focus on potential malignities and the subsequent need for abdominal (total) hysterectomy, even if the majority of large uterine growths consist of huge leiomyomata [1,2]. Uterine myomata are the most common benign tumours of the female genital tract; the cumulative incidence of uterine myomata in women during their reproductive years

\section{Zusammenfassung $\nabla$}

Die Uterusarterienembolisation (UAE) ist weltweit ein etabliertes Verfahren bei der Myombehandlung als Alternative zur Operation. Die Kombination beider Vorgehensweisen ist wenigen Fällen vorbehalten. Mit einer präoperativen UAE (PUAE) lassen sich Blutungskomplikationen vermindern und ein Uteruserhalt eher gewährleisten. Berichtet wird über 3 Patientinnen, bei denen wir einen solchen „interdisziplinären Hybrideingriff“ (Embolisation mit nachfolgender Operation) bei jeweils sehr großen Myomen (alle > $1100 \mathrm{~g}$ ) erfolgreich angewendet haben. Für alle 3 Patientinnen war der Uteruserhalt eine „conditio sine qua non“. PUAE kann, wie einige internationale Publikationen zeigen, bei Patientinnen in Erwägung gezogen werden, die den Uteruserhalt unbedingt wünschen, bei denen aber präoperativ bereits von einem erhöhten Blutungsrisiko ausgegangen und/oder bei denen das Risiko einer eventuell doch notwendigen Hysterektomie „aus technischen Gründen“ als hoch eingeschätzt wird. Zusatzkosten durch die Embolisationsmaßnahme stehen ein u.U. verkürzter Klinikaufenthalt durch einen günstigeren intra- und postoperativen Verlauf und die teilweise oder gänzliche Einsparung von Blutkonserven sowie eine große Zufriedenheit der behandelten Patientinnen gegenüber.

is around $70 \%$ for Caucasian women and over $80 \%$ for African-American women [3].

Apart from therapy using focussed ultrasound, a therapy which has several technical limitations, operative removal of the myoma is currently the only option for women who wish to have children after surgery. If the patient has stated her wish to preserve her uterus, the final decision on the appropriate therapy will also always include, irrespective of the patient's age, an assessment of the risk of patient having to undergo an (un- 
wanted) hysterectomy procedure and the potential necessity for blood transfusions in the "cost-benefit analysis".

In recent years, study groups in France, Great Britain and Turkey have reported on the use of planned preoperative uterine artery embolisation (PUAE) of large and/or multinodular uterine myomata performed immediately prior to myomectomy to improve the operative success of subsequent myoma enucleation and reduce intraoperative blood loss [4-6].

We present 3 patients in whom we performed such an interdisciplinary hybrid intervention (embolisation with subsequent surgery) to treat very large myomata. Preserving the uterus was a "sine qua non" for all 3 patients. All 3 patients were comprehensively informed preoperatively about the procedure and possible alternatives.

To our knowledge this is the first publication of this kind on a PUAE in Germany.

\section{Case Histories (cf. $\odot$ Table 1)}

$\nabla$

\section{Patient 1}

Patient 1 was a 43-year-old woman who urgently requested a uterus-preserving operation. On palpation the uterus was found to extend 2 fingers above the navel.

\section{MRT findings}

Myomatous uterus with multiple intramural and subserous leiomyomata with diameters of up to $11 \mathrm{~cm}$ ( Fig. 1).

\section{Uterine artery embolisation (UAE)}

A 5-French catheter (Roberts Uterine Curve) was introduced via the right femoral artery under local anaesthesia. This was followed by cannulation of the left internal iliac artery and of the uterine artery using a coaxial microcatheter. Selective angiogra-

Table 1 Subjective and objective data characterising the postoperative condition and satisfaction of the patients.

\begin{tabular}{|c|c|c|c|}
\hline & Patient 1 & Patient 2 & Patient 3 \\
\hline \multicolumn{4}{|l|}{ Haemoglobin (g/dl) } \\
\hline preoperatively & 12.6 & 12.9 & 11.3 \\
\hline at discharge & $9.3^{*}$ & 10.5 & 9.3 \\
\hline Sick leave (in weeks) & 9.5 & 14 & 5 \\
\hline $\begin{array}{l}\text { Impairment of daily activities } \\
\text { (in weeks) }\end{array}$ & 9 & none & 7 \\
\hline $\begin{array}{l}\text { Length of scar (ca. } 3 \text { months } \\
\text { postop.; in } \mathrm{cm} \text { ) }\end{array}$ & 12 & 15 & 11 \\
\hline $\begin{array}{l}\text { Diameter of largest myoma } \\
\text { (acc. histolog. findings; in cm) }\end{array}$ & $\begin{array}{l}11.5 \times \\
9 \times 8\end{array}$ & 18.5 & $\begin{array}{l}18 \times \\
15 \times 13\end{array}$ \\
\hline \multicolumn{4}{|l|}{ Postoperative condition $* *$} \\
\hline $\begin{array}{l}\text { with regard to myoma- } \\
\text { associated complaints }\end{array}$ & 9 & 5 & 10 \\
\hline with regard to general health & 8 & 4 & 8 \\
\hline \multicolumn{4}{|l|}{$\begin{array}{l}\text { Abdominal pressure/ } \\
\text { foreign body sensation*** }\end{array}$} \\
\hline preoperatively & 4 & $\begin{array}{l}\text { no infor- } \\
\text { mation }\end{array}$ & 4 \\
\hline - postoperatively & 0 & 0 & 0 \\
\hline $\begin{array}{l}\text { Recommend operation } \\
\text { to a friend }\end{array}$ & yes & yes & yes \\
\hline
\end{tabular}

* after transfusion of 2 units packed red blood cells

** Scale: 0 (=very bad) to 10 (= very good)

*** Scale: 0 (=none) to 10 (=maximum)

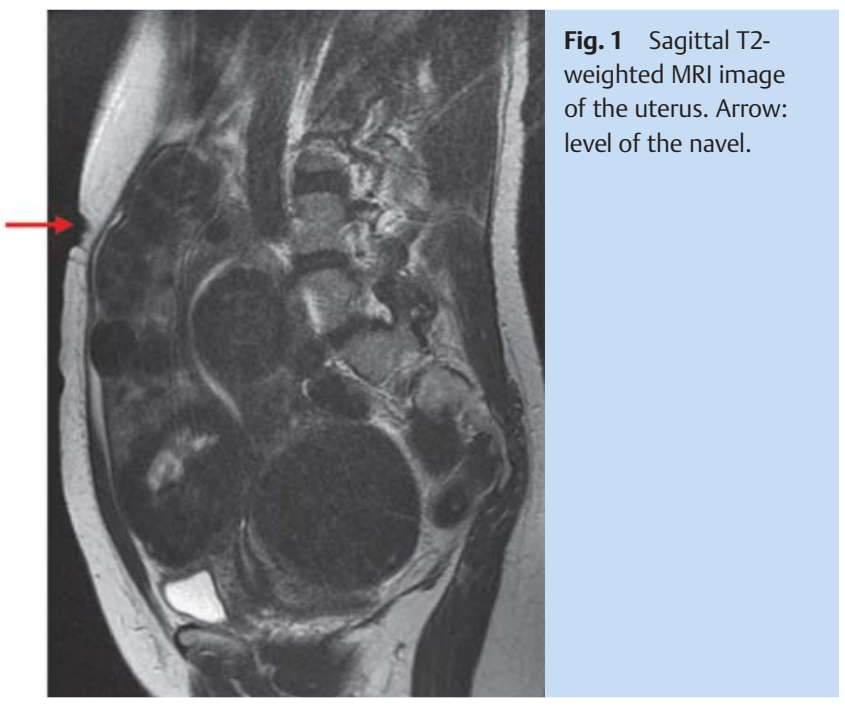

phy was done using iodine-containing contrast agents to visualise the anatomy. Free-flow embolisation was performed using microspheres with diameters of 700-900 micrometres (Embosphere) until incomplete stasis of blood flow in the ascending segment (arterial segment ascending along the uterus) of the left uterine artery was achieved. The catheter was retracted into the right pelvic axis and embolisation of the left uterine artery was carried out in a similar fashion. Subsequent analgesia consisted of fractionated administration of Dipidolor, metamizole (Novalmin) and paracetamol (Perfalgan) given as a short infusion as well as the concurrent oral administration of ibuprofen. Antiemetic management was done using metoclopramide and ondansetron, where necessary.

\section{Surgical operation}

Myoma enucleation was carried out via longitudinal laparotomy one day after uterine artery embolisation. Many subserous, intramural and partially submucosal myomata were found in the uterus. The largest myoma was a broad ligament fibroid, bigger than a man's fist, which extended to the right pelvic wall. At total of 20 myomata of varying sizes were removed.

\section{Histology}

Total weight $1565 \mathrm{~g}$, multiple leiomyoma nodules with regressive calcifications and localised necrosis after prior embolisation, no indications pf malignancy.

\section{Course}

The immediate postoperative course was unremarkable. Preoperative haemoglobin was $12.6 \mathrm{~g} / \mathrm{dl}$; however on the 2 nd day post operation haemoglobin values were $7.1 \mathrm{~g} / \mathrm{dl}$, and the patient was given a transfusion of 2 units of packed red blood cells. An antibiotic was administered until the 5th day postoperatively. The patient was discharged 8 days after surgery in good general health with a haemoglobin value of $9.3 \mathrm{~g} / \mathrm{dl}$. Wound healing was unremarkable.

\section{Patient 2}

Patient 2 was 40-year-old virgin with the wish to have children who urgently requested uterus-preserving surgery. On palpation, the patient was found to have a myomatous uterus extending to 
3 fingers under the costal arch; she did not report any symptoms; the secondary diagnosis was poorly controlled diabetes mellitus.

\section{MRT findings}

Myomatous uterus with a distance between the portio and the fundus of $19 \mathrm{~cm}$; extensive intramural lesion: myoma had a diameter of $141 \times 85 \times 155 \mathrm{~mm}$.

\section{UAE}

Procedure was as described for Patient 1 .

\section{Surgical operation}

Myomectomy was performed via longitudinal laparotomy carried out one day after embolisation of the uterine artery. A relatively soft myoma (clinical assessment: DD adenomyoma) with a diameter of $20 \times 15 \mathrm{~cm}$ which was difficult to separate from surrounding tissue was resected. The uterus was then subsequently closed in several layers with sutures and reconstructed. There was little bleeding.

\section{Histology}

Uterine leiomyoma, $1124 \mathrm{~g}, 210 \times 158 \times 57 \mathrm{~mm}$, no indications of malignancy.

\section{Course}

The postoperative course was unremarkable. Preoperative haemoglobin was $12.9 \mathrm{~g} / \mathrm{dl}$; postoperatively the haemoglobin value was $10.5 \mathrm{~g} / \mathrm{dl}$, no transfusion was required. The patient received antibiotics for 7 days; she was discharged on day 8 after surgery in good general health and with good primary wound healing of the longitudinal laparotomy incision.

\section{Patient 3}

A 51-year-old patient with a uterus which could be palpated 2 fingers above the navel and a large, dominant myoma of the anterior wall. Primary symptoms were abdominal pressure/discomfort. The patient urgently requested a uterus-preserving procedure.

\section{MRT findings \\ (Pt. refused MRT investigation.)}

\section{UAE}

Procedure was as described for Patient 1.

\section{Surgical operation}

Myoma enucleation was carried out one day after embolisation through longitudinal incision from the symphysis extending to 2 fingers below the navel. The dominant myoma was removed first, and the myoma bed was closed in 4 layers, followed by enucleation of 4 more subserous myomata. Intraoperative blood loss was approx. 800-900 ml.

\section{Histology}

Four fibrous nodules, diameter of the largest nodule $180 \times 150 \times 130 \mathrm{~mm}$, weight $2100 \mathrm{~g}$, no indications of malignancy.

\section{Course}

Preoperative haemoglobin was $11.3 \mathrm{~g} / \mathrm{dl}$, and postoperative haemoglobin was $9.3 \mathrm{~g} / \mathrm{dl}$. The patient received antibiotic prophylaxis perioperative and for 6 days postoperatively. The patient was discharged on the 7th postoperative day in good general health and with good primary healing of the longitudinal incision.

\section{Discussion \\ $\nabla$}

According to a study by Unger et al. (2002), hysterectomy patients with a uterine weight of more than $1000 \mathrm{~g}$ have a significantly higher risk of perioperative complications and are at greater risk of requiring a blood transfusion [7]. It is likely that this association also applies to myomata, depending on their weight or volume. While only 2 of the 3 patients with myomata weighing more than $1100 \mathrm{~g}$ presented here were able to avoid blood transfusion, the attempt to preserve the uterus was successful in all 3 patients.

The concept of PUAE, i.e. embolisation performed directly prior to operative myoma enucleation as a preparation for surgery, was originally developed in the 1990s by the Paris Working Group around Ravina $[8,9]$.

In 2004 Ngeh et al. reported on 5 patients with a large (up to the level of the navel or even higher) uterus and/or multiple myomata who underwent embolisation preoperatively to reduce/avoid the risk of hysterectomy and reduce the potential for severe blood loss. Blood loss was relatively low in all patients; no patient required blood transfusion subsequently. This was in marked contrast to the results reported for the control group [4]. In 2007, Dumousset et al. retrospectively evaluated the course after PUAE in 22 patients. Myoma removal was described as simpler by the surgeons, the intraoperative blood loss was estimated to be lower (mean value $90 \mathrm{ml}$ ), and no patient required blood transfusion [6].

In 2008, Tixier et al. published the retrospective results of 21 patients who underwent preoperative UAE prior to myomectomy. According to the surgeons, myoma removal was associated with only minimal loss of blood and suturing of the uterus intraoperatively was technically simpler [10]. Another group from France, Butori et al., reported in 2011 on a retrospective study of 33 women aged between 24 and 45 years with at least one myoma (mean diameter $9 \mathrm{~cm}[5-15 \mathrm{~cm}]$ ). Myomectomy was carried out either by laparotomy $(n=25)$ or laparoscopically $(n=8)$, and the surgeons reported that myoma removal was simpler. A comparison of postoperative haemoglobin values with postoperative values showed no significant differences; no patient required a blood transfusion [11].

Malartic et al. (2010) recommended carrying out a combination of UAE and myoma enucleation (conservative two-step procedure) in patients with very large $(>10 \mathrm{~cm}$ ) and/or multiple myomata (more than 10), who urgently requested uterus-preserving surgery [12]. Üstünsöz et al. (2010) made a similar recommendation after clinically examining 30 women with myomata $>10 \mathrm{~cm}$, half of whom had UAE prior to undergoing uterus-preserving surgery [5]. More recently, Goldman et al. (2012) reported on their results for UAE prior to laparoscopic myoma removal $(n=12)$. The myomata in the PUAE group were larger compared to the myomata in the untreated control group (595 vs. $154 \mathrm{~g}$ ); nevertheless, there was no significant difference between the groups with regard to operative times or blood loss [13]. Embolisation of the uterine artery has become an established procedure for the treatment of myomata as an alternative to full operative removal. However, the combination of both procedures, i.e. planned uterus-preserving operation directly after em- 
bolisation, is usually only carried out in a few cases and is still controversially discussed in some of the literature.

Our own experience and this brief overview of the literature show that UAE carried out preoperatively can contribute to reducing bleeding complications. Such a PUAE procedure should be considered and offered to patients who urgently request uterus preservation but who are already considered at high risk of bleeding complications preoperatively and/or who are also considered at high risk of requiring a hysterectomy "for technical reasons" (very large myomata and/or multiple myomata, myomata which are difficult to resect, myomata in an unfavourable location - cf. $[6,10,11])$.

The economic impact of PUAE is difficult to assess. The additional costs incurred with embolisation can be set off against the potentially shorter hospital stay due to the more favourable perioperative course, the savings if no or fewer blood transfusions are required and the satisfaction of the women undergoing treatment.

\section{Conflict of Interest}

$\nabla$

None.

\section{References}

1 Krämer B, Wallwiener D, Hönig A et al. Malignitätsverdacht bei riesigem Uterusmyom. Geburtsh Frauenheilk 2003; 63: 160-162

2 Steward RG, DenHartog HW, Katz AR. Giant uterine leiomyomata. Fertil Steril 2011; 95: 1121.e15-1121.e17
3 Day Baird D, Dunson DB, Hill MC et al. High cumulative incidence of uterine leiomyoma in black and white women: ultrasound evidence. Am J Obstet Gynecol 2003; 188: 100-107

4 Ngeh N, Belli AM, Morgan R et al. Pre-myomectomy uterine artery embolisation minimises operative blood loss. BJOG 2004; 111: 1139-1140

5 Ustünsöz B, Uğurel MS, Bozlar U et al. Is uterine artery embolization prior to myomectomy for giant fibroids helpful? Diagn Interv Radiol 2007; 13: 210-212

6 Dumousset E, Chabrot P, Rabischong B et al. Preoperative uterine artery embolization (PUAE) before uterine fibroid myomectomy. Cardiovasc Intervent Radiol 2008; 31: 514-520

7 Unger JB, Paul R, Caldito G. Hysterectomy for the massive leiomyomatous uterus. Obstet Gynecol 2002; 100: 1271-1275

8 Ravina JH, Bouret JM, Fried D et al. [Value of preoperative embolization of uterine fibroma: report of a multicenter series of 31 cases]. Contracept Fertil Sex 1995; 23: 45-49

9 Ravina JH, Herbreteau D, Ciraru-Vigneron $N$ et al. Arterial embolisation to treat uterine myomata. Lancet 1995; 346: 671-672

10 Tixier H, Loffroy R, Filipuzzi L et al. Embolisation artérielle utérine par matériel résorbable avant myomectomie [Uterine artery embolization with resorbable material prior to myomectomy]. J Radiol 2008; 89: 1925-1929

11 Butori N, Tixier H, Filipuzzi L et al. Interest of uterine artery embolization with gelatin sponge particles prior to myomectomy for large and/ or multiple fibroids. Eur J Radiol 2011; 79: 1-6

12 Malartic C, Morel O, Fargeaudou Y et al. Conservative two-step procedure including uterine artery embolization with embosphere and surgical myomectomy for the treatment of multiple fibroids: preliminary experience. Eur J Radiol 2012; 81: 1-5

13 Goldman KN, Hirshfeld-Cytron JE, Pavone ME et al. Uterine artery embolization immediately preceding laparoscopic myomectomy. Int J Gynaecol Obstet 2012; 116: 105-108

Deutschsprachige Zusatzinformationen online abrufbar unter: www.thieme-connect.de/ejournals/toc/gebfra. 